\title{
Physical Activity versus Sclerostin and Interleukin 6 Concentration in Patients Receiving Renal Replacement Therapy by Hemodialysis
}

This article was published in the following Dove Press journal: Risk Management and Healthcare Policy

\author{
Agnieszka Turoń-Skrzypińska ${ }^{1, *}$ \\ Grażyna Dutkiewicz ${ }^{2} *$ \\ Małgorzata Marchelek- \\ Myśliwiec $^{2}$ \\ Aleksandra Rył \\ Violetta Dziedziejko (iD ${ }^{3}$ \\ Krzysztof Safranow $\mathbb{D}^{3}$ \\ Kazimierz Ciechanowski (iD ${ }^{2}$ \\ Iwona Rotter (ID) \\ 'Department of Medical Rehabilitation \\ and Clinical Rehabilitation, Pomeranian \\ Medical University, Szczecin 7I-2I0, \\ Poland; ${ }^{2}$ Department of Nephrology, \\ Transplantology and Internal Medicine, \\ Pomeranian Medical University, Szczecin \\ 70-III, Poland; ${ }^{3}$ Department of \\ Biochemistry and Medical Chemistry, \\ Pomeranian Medical University, Szczecin \\ 70-1II, Poland \\ *These authors contributed equally to \\ this work
}

Introduction: Chronic kidney disease and renal replacement therapy are associated with reduced motor activity, which may result in the presence of mineral bone disorders and an increase in inflammation markers. The aim of the study was to assess the relationship between the performance of daily physical activity, expressed in the number of steps performed by patients undergoing hemodialysis and the concentration of selected biochemical parameters (SCL, IL-6).

Patients and Methods: The study group (B) involved 33 patients aged $59.8 \pm 9.8$ years from the dialysis station at the Department of Nephrology, Transplantology and Internal Medicine PUM. In group B, interventions considering an increase in physical activity expressed in the number of steps were introduced. Group C consisted of 30 people aged 54.9 (9.37), with GFR over $60 \mathrm{~mL} / \mathrm{min} / 1.73 \mathrm{~m}$. Physical activity was measured with pedometers. Anthropometric and biochemical parameters were assessed at baseline, after the third and sixth month of the study. Descriptive statistics, intergroup comparisons using Mann-Whitney $U$ test and Spearman correlation analysis were performed. The level of significance was set at $\mathrm{p} \leq 0.005$.

Results: A relationship between IL- 6 concentration and the number of steps in group B after three months of intervention was demonstrated. In group C, the concentration of SCL and IL6 decreased with the increase in the number of steps taken. Only in group $C$ the waist circumference decreased with the increase of the number of steps performed.

Conclusion: Patients receiving renal replacement therapy by hemodialysis showed significantly lower physical activity compared to people without kidney disease. Performing bigger number of steps can lower interleukin 6 levels in hemodialysis patients.

Keywords: physical activity, hemodialysis, sclerostin, interleukin 6

\section{Introduction}

Chronic Kidney Disease (CKD) is a major public health problem associated with reduced motor activity. This may result in the occurrence of mineral and bone disorders and an increase in the concentration of inflammation markers. ${ }^{1}$

The key role in regulating bone mass and inhibiting anabolic processes of bone formation plays, among others sclerostin - a glycoprotein encoded within chromosome 17 (region $17 q 12-q 21$ ) in the proximity of the SOST gene. ${ }^{2-4}$ Mechanical stress is a key regulator that controls bone formation and remodelling involving osteocytes. An increase in concentration of sclerostin (SCL) has been observed from stage 3 of CKD. In patients with end-stage renal disease, it is several times higher compared to the population with normal renal function. ${ }^{5-10}$

Correspondence: Agnieszka TurońSkrzypińska

Email agi.skrzypinska@gmail.com
Risk Management and Healthcare Policy 2020:I3 |467-|475

1467

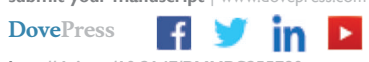

hotp:/doiorg/ 10.2147 iRMHP.S255t 
Sclerostin is a protein secreted by osteocytes that has properties that inhibit bone formation. The SOST/sclerostin system plays a key role in regulating bone mass and inhibiting anabolic processes of bone formation by inhibiting the osteoblastic line. Daily physical activity stimulates osteogenesis and myogenesis, and immobility adipogenesis. The osteogenic and muscle-forming effect arises due to the mechanism of the muscle pump (muscle contraction and relaxation) inhibiting the synthesis of sclerostin. Muscle mass increases and decreases simultaneously with bone mineral density (BMD). Osteopenia accompanies sarcopenia. Greater release of sclerostin by osteocytes is observed in people with low physical activity. This is the result of insufficient bone stress and insufficient bone loading. In people who exercise regularly, the secretion of sclerostin protein is inhibited, resulting in greater bone mass. In addition, this protein plays a significant role as a stimulator of osteoblastogenesis, and its concentrations or differences in serum concentrations can be considered a potentially important parameter in monitoring and predicting the further course of therapy. ${ }^{1-10}$

The occurrence of inflammation and reduced muscle clearance is associated, among others with an increase in the concentration of interleukin 6 (IL-6) - a pleiotropic cytokine (a $26 \mathrm{kDa}$ protein) encoded by a gene located on the short arm of chromosome $7(7 \mathrm{p} 15-\mathrm{p} 21) .{ }^{11-13}$ The increase in IL-6 concentration occurs already in the early stages of CKD and reaches a significantly higher level in patients treated with hemodialysis. ${ }^{14,15}$

Deterioration of health, malaise and treatment with hemodialysis makes it difficult for patients to perform physical exertion. In addition, a group of patients treated with renal replacement therapy may present a negative attitude to physical effort, and cooperation with them in this aspect can be difficult. In the literature there are also publications describing ways of motivation and overcoming barriers by patients undergoing hemodialysis, such as: encouraging physical effort by discussing the benefits of regular physical activity, introduction of devices measuring physical activity or introduction of an element of competition between patients. ${ }^{16-19}$

It is important to encourage patients undergoing hemodialysis to physical therapy and modification of their lifestyle by increasing the attractiveness of exercise, monitoring physical activity and highlighting the benefits of regular exercise. ${ }^{20-23}$

The available literature lacks comparative studies on the relationship between regular physical activity and the value of interleukin 6 and sclerostin concentration in patients treated with hemodialysis. Therefore, it is justified to supplement these reports.

The aim of the study was to assess the effect of regular six-month physical activity measured by the number of steps on the plasma concentration of sclerostin and interleukin 6 and selected anthropometric parameters in the group of patients receiving renal replacement therapy by hemodialysis.

\section{Patients and Methods Group Characteristics}

The study included 34 patients (study group - B) treated with renal replacement therapy by hemodialysis, with complete absence of diuresis for at least three months, and with a frequency of three hemodialysis sessions a week. The mean duration of a single hemodialysis session was $242.6 \pm 25.2 \min (\mathrm{X} \pm \mathrm{SD})$, and the average duration of hemodialysis treatment was 56 months. During the week, the patient was subjected to dialysis three times.

The control group (C) was selected from the general population, reporting at follow-up visits at a family physician's office. The control group was tested for renal function. A general urine test and morphology were performed, the levels of creatinine, urea and total proteins were determined and the glomerular filtration rate (GFR) was calculated. Thirty-one people with GFR over $60 \mathrm{~mL} /$ $\mathrm{min} / 1.73 \mathrm{~m}^{2}$ were randomly qualified for the study.

The study group (B) was selected for the study based on qualification and disqualification criteria. The criteria qualifying for the research project were: written consent to participate in the study, complete absence of diuresis, inclusion in the renal replacement therapy by hemodialysis program for at least 3 months (with a frequency of three times a week), age over 18 years. Each patient enrolled in the study achieved $\mathrm{Kt} / \mathrm{V}$ above 1.2 of the last three months before entering the study. The criteria disqualifying for participation in the research project were: lack of consent to participate in the study, musculoskeletal disorders preventing participation in the study, cardiovascular diseases preventing participation in the study, not correctable vision disorders, poorly controlled diabetes (HbAlc levels of over $8 \%$ for 3 months), senile dementia, depression or other mental illnesses; cancer.

The study included all patients participating in the program of renal replacement therapy by hemodialysis who gave written consent to participate in the study and met the inclusion criteria. Fifty-three patients with renal replacement therapy by hemodialysis ( 28 men, 25 women) were qualified 
for the study (Figure 1), 11 people (5 women and 6 men) did not agree to participate in the research project, justifying this decision with their reluctance to perform physical activity. Three people (1 man, 2 women) died during the research project, one man had a kidney transplant, and 5 people (1 man, 4 women) resigned from the participation in the study. Eventually, 33 people (20 men and 13 women) completed the study. Patients undergoing hemodialysis received vita$\min \mathrm{D}$ in the form of $1.25(\mathrm{OH}) 2 \mathrm{D} 3$ at a dose of 0.2 to $1 \mathrm{ug}$ per day. Concentrations in this group of patients were above the lower limit of the norm. Patients recruited for the control group by the family doctor had vitamin D deficiencies excluded before the study.

The control group (C) was also selected based on the inclusion and exclusion criteria for the research project. The inclusion criteria were: consent to participate in the study, age over eighteen, normal renal function. The exclusion criteria were the same as in the study group.

There were no statistically significant differences in the mean values of systolic and diastolic pressure and pulse between the groups. Patients selected for the study did not declare any other chronic diseases.

\section{The Course of the Study}

All participants were informed about the purpose of the study. The study subjects were given Beurer AS 50 pedometers. Data such as date, time, body weight, step length have been entered into the patient's device and sensitivity of the device was set (in the study group on a day without hemodialysis).

Participants in study and control group were asked to perform only physical activity, which can be measured with a pedometer 3 months before the start of the research project and during its duration.

The subjects belonging to the $\mathrm{B}$ and $\mathrm{C}$ groups were trained to use the pedometer. Participants in the research program were required to wear the device all the time in one place (on a belt, on a chain or in a pocket), throughout the whole duration of the study, excluding sleep and bath time.

The study was conducted in line with the principles stated in the Declaration of Helsinki. The study was approved by the Pomeranian Medical University Commission of

Ethics-Resolution No. KB-0012/40/13. The research was conducted in the years 2014-2019. Data were collected three times: upon study inclusion (E0) and after the third month of the research (E3).

At the time of joining the study, patients were asked to complete an original questionnaire prepared for the purposes of the study, containing demographic questions about the participant's health and lifestyle.

Selected biochemical blood measurements (determination of sclerostin and interleukin 6 levels) and anthropometric measurements were taken at two time points (E0) the baseline measurement at the start of the study, (E3) after three months. In the study group, measurements were

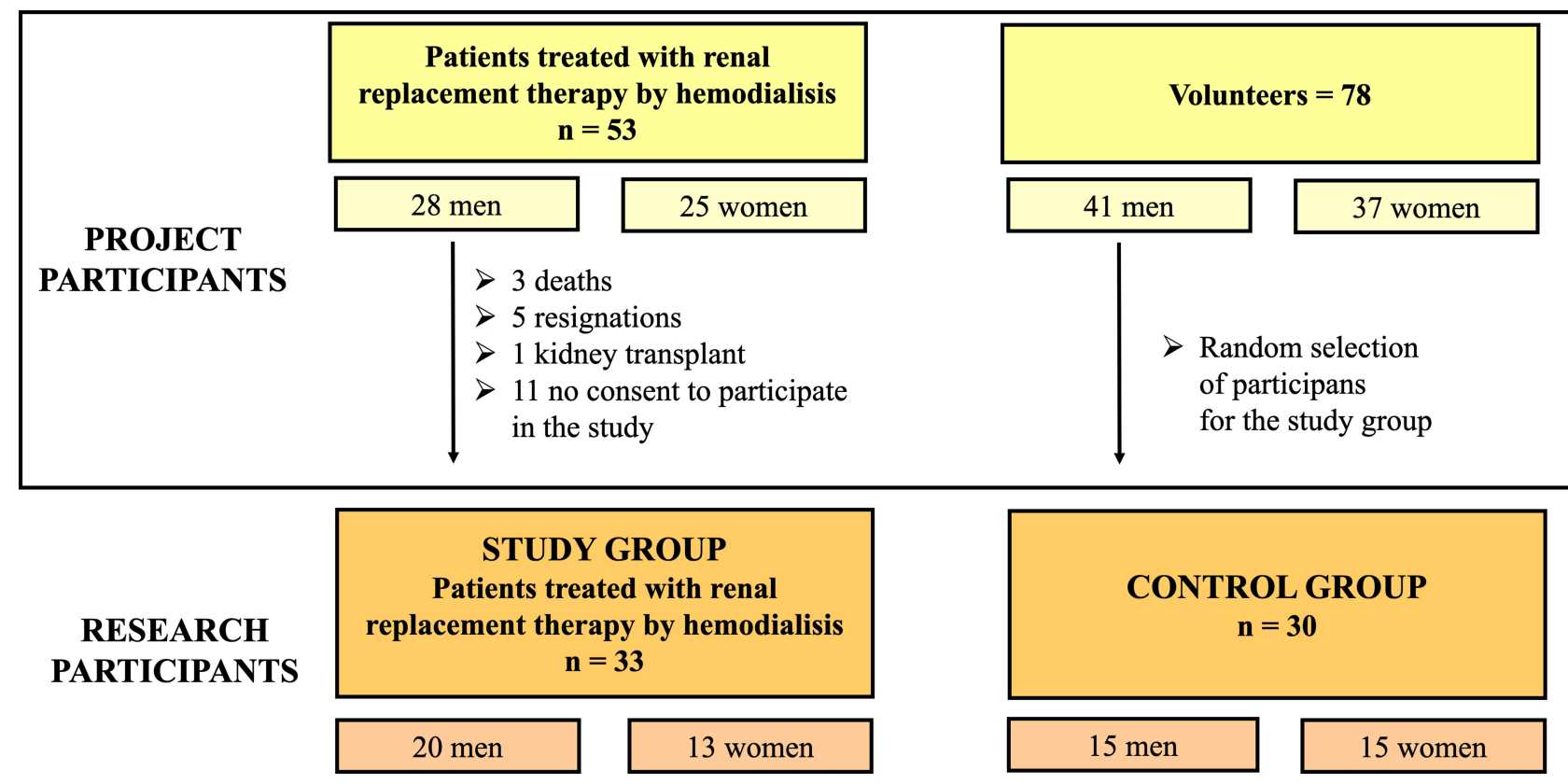

Figure I Research qualification scheme. 
taken 20-30 minutes after completion of hemodialysis in an examination room.

Patient height was measured. It was measured from the floor to the head vertex with a height meter attached to an electronic scale. Body weight was measured with an accuracy of $10 \mathrm{~g}$ using the same electronic scale. Waist and hip circumferences were measured using a centimetre-scale body measuring tape. Weight-height proportions were assessed using the BMI (Body Mass Index). ${ }^{24,25}$

The participants of the study and control groups had 2 $\mathrm{mL}$ of blood collected. Patients with end-stage renal disease treated with hemodialysis had blood taken from a venous line of the dialysis shunt in EDTA tubes prior to hemodialysis, at the dialysis station at the Department of Nephrology, Transplantology and Internal Medicine, Pomeranian Medical University, on the day of periodic blood tests at E0, E3. The blood samples were centrifuged (4000 rpm for 10 minutes) at $4^{\circ} \mathrm{C}$ in an MPW-350R centrifuge. Plasma samples were divided into $200 \mu \mathrm{L}$ aliquots, placed into two separate Eppendorf tubes $(1.0 \mathrm{~mL}$ Eppendorf Quality ${ }^{\mathrm{TM}}$ Safe-Lock tubes, colourless) and immediately frozen. Until the determination, the samples were stored at $-170^{\circ} \mathrm{C}$. Freshly thawed portions were used for the laboratory analysis. The assessment of concentrations of IL-6 and sclerostin in plasma was performed with the use of a commercially available ELISA kit (Quantikine High Sensitivity ELISA kit, R\&D Systems Europe). The concentration of sclerostin (SCL) and interleukin 6 (IL-6) is given in picograms per millilitre $[\mathrm{pg} / \mathrm{mL}]$.

\section{Statistical Analysis}

All statistical calculations were performed using the statistical package STATISTICA (data analysis software system version 12.0).

Quantitative variables were characterized by an arithmetic mean, standard deviation, median, minimum and maximum values. Qualitative variables were presented by absolute counts and percentages. Normal distribution was tested using the Shapiro Wilk test. The Mann-Whitney U test was used to assess the significance of differences between the two groups. The significance of differences between more than two groups was verified by the Kruskal-Wallis test. In the event of statistically significant differences between the groups, post hoc tests were used (Dunn's test). Correlation analysis by calculating correlation coefficients or Spearman's rank coefficients was performed to determine the relationship of strength and direction between variables. In all calculations, the level of significance was set at $\mathrm{p} \leq 0.05$.

\section{Results}

The study and control groups differed from each other in the analysis of the number of hospitalizations per year ( $p$ $<0.001)$. The analysed groups also differed from each other in the analysis of the WHR index $(p=0.007)$ and in the analysis of the concentration of interleukin- 6 both in the baseline measurement of this parameter $(\mathrm{p}<0.001)$ and after three months $(\mathrm{p}<0.001)$ (Table 1) 78 people (41 men, 37 women) volunteered to participate in the research project (Figure 1). Eventually, 30 people (15 men, 15 women) were randomly qualified for the study.

The research involved an analysis comparing the study groups and control group in terms of the number of steps performed (Table 2).

The correlation between the number of steps in the study and control groups and the concentration of sclerostin and interleukin was examined after 0 and 3 months.

During the analysis of the correlations, it was shown that the number of steps in the third month of the study correlates with the SCL concentration $(\mathrm{R}=-0.386$, $\mathrm{p}=0.029$ ) but this relationship was observed only in group C. The relationship between IL-6 concentration and the number of steps in group $\mathrm{B}$ after three months of intervention $(\mathrm{R}=-0.434, \mathrm{p}=0.010)$ and in group $\mathrm{C}(\mathrm{R}=$ $-0.393, \mathrm{p}=0.018$ ) was demonstrated (Table 3 ).

Correlations between the number of steps in the study and control groups were also analyzed in terms of age, body weight, BMI (Table 4). It was shown that the only anthropometric parameter correlating with the number of steps during the intervention was the age of the patients $(\mathrm{R}=-0.394, \mathrm{p}=0.021)$. No relationship was observed in the analysis of the other parameters.

\section{Discussion}

The literature describes many benefits of exercising and increasing regular physical activity for the health and wellbeing of patients with chronic kidney disease. ${ }^{26-29}$ Despite this fact, the level of physical activity in this group of patients is significantly lower compared to people with normal renal function. ${ }^{30,31}$ The presented work showed that despite the introduced intervention, the total number of steps performed was significantly lower in periods of 0 3 in groups B compared to C. Similar relationships have been found in publications of other authors. ${ }^{32,33}$ This could be influenced by complications associated with chronic 
Table I Basic Characteristics of the Study Group and the Control Group

\begin{tabular}{|c|c|c|c|c|c|c|c|}
\hline \multirow[t]{2}{*}{ Variable } & \multicolumn{3}{|c|}{ Group B } & \multicolumn{3}{|c|}{ Group C } & \multirow[t]{2}{*}{$\mathbf{p}$} \\
\hline & Me & 25th Percentile & 75th Percentile & Me & 25th Percentile & 75th Percentile & \\
\hline \multicolumn{8}{|l|}{ Baseline measurement data } \\
\hline Age [years] & 60.50 & 56.00 & 67.00 & 58.50 & 49.00 & 61.50 & 0.061 \\
\hline Body weight $[\mathrm{kg}]$ & 75.00 & 64.30 & 81.50 & 78.50 & 65.50 & 91.50 & 0.496 \\
\hline BMI $\left[\mathrm{kg} / \mathrm{m}^{2}\right]$ & 25.34 & 22.38 & 28.71 & 25.87 & 24.01 & 29.86 & 0.339 \\
\hline Waist circumference $[\mathrm{cm}]$ & 97.00 & 88.00 & 105.00 & 88.50 & 82.00 & 100.00 & 0.055 \\
\hline Hip circumference $[\mathrm{cm}]$ & 102.00 & 96.00 & 106.00 & 103.00 & 97.50 & 106.50 & 0.812 \\
\hline WHR & 0.94 & 0.87 & 1.01 & 0.90 & 0.80 & 0.94 & $0.007^{*}$ \\
\hline Hospitalizations & 2.50 & 1.00 & 4.00 & 0.00 & 0.00 & 0.00 & $\mathrm{p}<0.00 \mathrm{I} *$ \\
\hline SCL (baseline) & 425.10 & 293.31 & 609.97 & 364.55 & 318.59 & 467.10 & 0.369 \\
\hline IL-6 (baseline) & 4.44 & 2.74 & 8.23 & 0.97 & 0.59 & 1.92 & $\mathrm{p}<0.001 *$ \\
\hline \multicolumn{8}{|c|}{ Measurement data after 3 months of study } \\
\hline SCL (third month) & 379.67 & 263.99 & 479.99 & 403.11 & 321.98 & 457.11 & 0.386 \\
\hline IL-6 (third month) & 4.56 & 3.32 & 7.22 & 1.04 & 0.55 & 1.77 & $\mathrm{p}<0.001 *$ \\
\hline
\end{tabular}

Abbreviations: p*, Mann-Whitney U test; BMI, body mass index; Me, median; Group B, study group; Group C, control group; *, statistically significant parameter.

Table 2 Comparative Characteristics of the Study Group (B) and Control Group (C) by Number of Steps

\begin{tabular}{|c|c|c|c|c|c|c|c|}
\hline & \multicolumn{3}{|c|}{ Group B } & \multicolumn{3}{|c|}{ Group C } & \multirow[t]{2}{*}{$P$-value } \\
\hline & Me & 25th Percentile & 75th Percentile & Me & 25th Percentile & 75th Percentile & \\
\hline Steps $0-3$ mth & 546.23 & 402.23 & 691.05 & 855.22 & 825.33 & 1026.04 & $\mathrm{p}<0.00 I^{*}$ \\
\hline
\end{tabular}

Abbreviations: Group C, control group; Group B, study group; p-value, statistical significance; *, statistically significant parameter.

Table 3 Correlation Analysis of the Number of Steps in the Study and Control Groups and the Concentration of Sclerostin and Interleukin After 0 and 3 Months ( - Correlation Coefficient)

\begin{tabular}{|l|l|l|l|l|l|}
\hline \multicolumn{2}{|c|}{} & \multicolumn{2}{l|}{ Group B } & \multicolumn{2}{l|}{ Group C } \\
\cline { 3 - 6 } \multicolumn{2}{|c|}{} & R & P-value & R & P-value \\
\hline SCL (3 mth) & Average & -0.187 & 0.288 & -0.386 & $0.029^{*}$ \\
IL-6 (3 mth) & number & -0.434 & $0.010^{*}$ & -0.393 & $0.018^{*}$ \\
& $\begin{array}{l}\text { of steps } \\
\end{array}$ & & & & \\
& over 3 & & & & \\
& months & & & & \\
\hline
\end{tabular}

Note: Spearman's $\rho$ correlation test.

Abbreviations: Group C, control group; Group B, study group; SCL, sclerostin concentration; IL-6, interleukin 6 concentration; R, correlation coefficient; $\mathrm{p}$-value, statistical significance; *, statistically significant parameter.

kidney disease and renal replacement therapy, as well as by a lack of motivation to exercise. ${ }^{34-37}$

There are many works in which, similarly to the conducted research project, pedometers or accelerometers were used in AF studies as well as tools for monitoring and motivating of renal replacement patients to exercise. ${ }^{16,17,38,39}$ It is important that in the presented studies out of 53 patients
Table 4 Correlation Analysis of the Number of Steps in the Study and Control Groups in Terms of Age, Body Weight, BMI (R - Correlation Coefficient)

\begin{tabular}{|l|l|l|l|l|l|}
\hline \multicolumn{2}{|c|}{} & \multicolumn{2}{|l|}{ Group B } & \multicolumn{2}{l|}{ Group C } \\
\cline { 3 - 6 } \multicolumn{2}{|c|}{} & R & P-value & R & P-value \\
\hline $\begin{array}{l}\text { Average } \\
\text { number } \\
\text { of steps } \\
\text { over 3 } \\
\text { months }\end{array}$ & $\begin{array}{l}\text { Body weight (3) } \\
\text { mth) }\end{array}$ & 0.249 & 0.155 & -0.013 & 0.943 \\
& BMl (3 mth) & 0.290 & 0.097 & -0.058 & 0.753 \\
& $\begin{array}{l}\text { Waist } \\
\text { circumference }\end{array}$ & 0.222 & 0.207 & 0.008 & 0.964 \\
& (3 mth) & & & & \\
& Age & -0.394 & $0.021 *$ & -0.197 & 0.279 \\
\hline
\end{tabular}

Note: Spearman's $\rho$ correlation test.

Abbreviations: Group C, control group; Group B, study group; BMI, body mass index; R, correlation coefficient; $\mathrm{p}$-value, statistical significance; *, statistically significant parameter.

qualified by a nephrologist only 43 persons entered the study. In the study group, there were no patients who stopped performing the intervention. The only exception resulting in cessation of physical activity were independent factors, such as kidney transplantation to a patient treated with renal replacement therapy or death. Prescribed physical exercise 
performed by hemodialysis patients was completely safe and did not adversely affect their health.

Mechanical stress is a key regulator that controls bone formation and remodelling involving osteocytes. Sclerostin is produced and released by mature osteocytes on the bone surface, where it inhibits osteoblast transmission and signals activating differentiation from mesenchymal cells, thereby inhibiting new bone formation. There are few publications in the literature on the effect of physical training on the concentration of SCL in peripheral blood. ${ }^{40-42}$ In turn, Frings-Meuthen et al, when examining SCL concentration in young healthy men, observed an increase in the concentration of this protein after 14 days of immobilization in the supine position. ${ }^{41,43}$ These observations were confirmed in the work of Gaudio et al who checked the influence of immobilization on SCL concentration in postmenopausal women. ${ }^{44}$

For example, Ardawi et al assessed the impact of walking or exercise on SCL concentration and showed that the concentration of this protein decreased with increasing duration of physical activity. ${ }^{42}$ It can therefore be concluded that the concentration of sclerostin in the blood may drop after properly planned physical training. In this study, for the first time, an attempt was made to assess the relationship between regular physical activity expressed in the number of steps and sclerostin concentration in patients receiving renal replacement therapy by hemodialysis. A negative correlation between SCL level in blood after the 3rd month of the research project and the total number of steps performed in $\mathrm{C}$ groups after 0-3 months was presented.

In the available literature, no research was found that would be based on a similar analysis in the group of patients treated with hemodialysis. Preliminary studies have shown that there may be a relationship between physical activity expressed in the number of steps and sclerostin concentration in patients treated with hemodialysis. It is worth considering performing similar studies not only in the group of hemodialysis patients, but also among patients treated with other methods of renal replacement therapy.

IL-6 levels are often elevated in patients with CKD, especially those treated with dialysis. Lack or reduced physical activity may result in an increase in inflammation among people with chronic kidney disease. ${ }^{45}$ In turn, regular exercise is particularly important in people with chronic kidney disease because it has anti-inflammatory effects. $^{46}$
Many studies have been published on the relationship between physical activity and IL- 6 concentration in hemodialysis patients, but no studies evaluating the correlation between the number of steps performed and the concentration of this cytokine in hemodialysis patients have been found. ${ }^{47,48}$

This study evaluated the relationship between regular physical activity expressed in the number of steps and IL-6 concentration in hemodialysis patients. In the study and control groups, the IL- 6 concentration decreased with the increase in the number of steps after 3 months of studies. Similar studies performed in the group of patients treated with hemodialysis were not found in the literature. In the research of Dungey et al and Chema et al there was no significant relationship between the performance of physical activity during dialysis and IL-6 levels, because prescribed physical activity in the group of patients treated with hemodialysis may not have reached sufficient intensity, the occurrence of chronic inflammation or high individual variability among patients on dialysis could have affected the absence of significant changes in IL-6 levels. In turn, in studies conducted in other groups of patients results confirming the relationship between physical activity and the concentration of inflammation markers were obtained in other studies. ${ }^{49-51}$ Adequate physical activity reduces the level of inflammation markers.

As a result of the analysis, no significant correlations were found between performing the intervention and body weight, as well as BMI in the examined groups. Similar results were obtained by Dungey et al who analyzed the impact of regular exercise during hemodialysis on anthropometric parameters. ${ }^{14}$

The study showed that there is a negative correlation between the total number of steps performed and waist circumference in the control group. Research by Huang et al showed that people who exercise systematically have a lower waist circumference. ${ }^{52}$

There are few publications assessing the impact of exercise on anthropometric parameters in hemodialysis patients, such as BMI and body weight, ${ }^{53}$ which may be due to problems arising from the overhydration of patients in the period between dialysis.

Regular physical activity positively affects the physical and mental functioning of a person. Studies have shown that with age deterioration of the body's cognitive functions, sarcopenia or a decrease in bone mineral density may occur. Age is a good predictor of health condition. However, there is a large individual variability showing 
that some elderly people are in good health, while others are weak or disabled. ${ }^{54}$ In this study, a negative correlation between age and physical activity expressed in the number of steps was confirmed only in the control group. The absence of these relationships among the participants of the study group may be due to their chronic kidney disease, conducted renal replacement therapy or post-dialysis complications, such as fatigue.

\section{Limitations}

The obtained results were influenced by the worsening condition of patients with CKD, renal replacement therapy and the occurrence of various comorbidities. In the study of patients with chronic kidney disease treated with hemodialysis, it was difficult to find people willing to participate in the project assessing their AF. It was also necessary to choose physical activity in a way, which allowed the participants to be able to perform the recommended intervention. The size of the study group during the research project decreased for independent reasons, such as kidney transplants and deaths among project participants. In the study, the psychological aspect of having a pedometer could have made the hemodialysis patients more willing to perform physical activity, even when they did not have the recommended intervention. This could have been an independent factor influencing the course of the study. In the continuation of research, it is necessary to increase the size of the study group, which would allow a more accurate analysis of these relationships.

\section{Conclusions}

The studies showed that regular physical activity expressed in the number of steps may have an impact on lowering the concentration of the biochemical parameters tested (interleukin 6), but it does not affect the BMI, body weight, waist circumferences in the group of patients treated with hemodialysis. In turn, in the group of patients without end-stage kidney disease, a bigger number of steps performed is associated with lower values of both interleukin 6 and sclerostin levels. The key factor is to encourage patients with end-stage renal disease who are being treated with hemodialysis to exercise regularly, as they show significantly lower physical activity compared to patients with normal renal function.

\section{Author Contributions}

Agnieszka Turoń-Skrzypińska is the co-corresponding author. All authors made a significant contribution to the work reported, whether that is in the conception, study design, execution, acquisition of data, analysis and interpretation, or in all these areas; took part in drafting, revising or critically reviewing the article; gave final approval of the version to be published; have agreed on the journal to which the article has been submitted; and agree to be accountable for all aspects of the work.

\section{Funding}

This research received no external funding.

\section{Disclosure}

The authors report no conflicts of interest in this work.

\section{References}

1. Barcellos FC, Santos IS, Umpierre D, Bohlke M, Hallal PC. Effects of exercise in the whole spectrum of chronic kidney disease: a systematic review. Clin Kidney J. 2015;8(6):753-765. doi:10.1093/ ckj/sfv099

2. Brandenburg VM, D'Haese P, and Deck A, et al. From skeletal to cardiovascular disease in 12 steps - the evolution of sclerostin as a major player in CKD-MBD. Pediatr Nephrol. 2016;31(2):195-206. doi:10.1007/s00467-015-3069-7

3. Wang XH, Mitch WE. Mechanisms of muscle wasting in chronic kidney disease. Nat Rev Nephrol. 2014;10(9):504-516. doi:10.1038/ nrneph.2014.112

4. Xiong L, Jung J-U, Wu H, et al. Lrp4 in osteoblasts suppresses bone formation and promotes osteoclastogenesis and bone resorption. Proc Natl Acad Sci. 2015;112(11):3487-3492. doi:10.1073/pnas.14197 14112

5. Bonani M, Rodriguez D, Fehr T, et al. Sclerostin blood levels before and after kidney transplantation. Kidney Blood Press Res. 2014;39 (4):230-239. doi:10.1159/000355781

6. Brown JP, Albert CA, Nassar BA, et al. Bone turnover markers in the management of postmenopausal osteoporosis. Clin Biochem. 2009;42 (10-11):929-942. doi:10.1016/j.clinbiochem.2009.04.001

7. Desjardins L, Liabeuf S, Oliveira RB, et al. Uremic toxicity and sclerostin in chronic kidney disease patients. Nephrol Ther. 2014;10 (6):463-470. doi:10.1016/j.nephro.2014.04.002

8. Evenepoel P, Claes K, and Viaene L, et al. Decreased circulating sclerostin levels in renal transplant recipients with persistent hyperparathyroidism. Transplantation. 2016;100(10):2188-2193. doi:10.10 97/TP.0000000000001311

9. Jean G, Chazot C, Bresson E, Zaoui E, and Cavalier E. High serum sclerostin levels are associated with a better outcome in haemodialysis patients. Nephron. 2016;132(3):181-190. doi:10.1159/0004 43845

10. Moysés RMA, Jamal SA, Graciolli FG, Dos Reis LM, Elias RM. Can we compare serum sclerostin results obtained with different assays in hemodialysis patients? Int Urol Nephrol. 2015;47(5):847-850. doi:10.1007/s11255-015-0971-7

11. Buczko W, Danysz A. Kompendium Farmakologii i Farmakoterapii. Wyd.6 Wrocław: edra Urban\&Partner; 2016. ISBN: 978-83-6537327-4.

12. Gołąb J, Jakóbisiak M, Lasek W, Stokłosa T. Immunologia. Wyd.7. Warszawa: wydawnictwo Naukowe PWN; 2017. ISBN: 97883 01194505.

13. Mutschler E, Geisslinger G, Kroemer HK, et al.: Mutschler - farmakologia i toksykologia. Podręcznik. Wrocław: medPharm Polska; 2016. ISBN: 9788378460374 
14. Dungey M, Young HML, Churchward DR, Burton JO, Smith AC, Bishop NC. Regular exercise during haemodialysis promotes an antiinflammatory leucocyte profile. Clin Kidney J. 2017;10(6):813-821. doi: $10.1093 / \mathrm{ckj} / \mathrm{sfx} 015$

15. Turoń-Skrzypinska A, Dutkiewicz G, and Marchelek-Mysliwiec M. Assessment of sclerostin and interleukin 6 levels and selected anthropometric parameters in patients receiving hemodialysis replacement therapy - pilot study . Medicina. 2019;55(12):15. doi:10.3390/ medicina55120784

16. Hiraki K, Shibagaki Y, Izawa KP, et al. Effects of home-based exercise on pre-dialysis chronic kidney disease patients: a randomized pilot and feasibility trial. BMC Nephrol. 2017;18(1):198. doi:10.1186/s12882-017-0613-7

17. Akber A, Portale AA, Johansen KL. Use of pedometers to increase physical activity among children and adolescents with chronic kidney disease. Pediatr Nephrol. 2014;29(8):1395-1402. doi:10.1007/ s00467-014-2787-6

18. Hanan M, and Bronas U. Barriers to exercise for patients with renal disease: an integrative review. $J$ Nephrol. 2017;30(6):729-741. doi:10.1007/s40620-017-0420-z

19. Jhamb M, McNulty M, and Ingalsbe G, et al. Knowledge, barriers and facilitators of exercise in dialysis patients: a qualitative study of patients, staff and nephrologists. BMC Nephrol. 2016;17(1):192. doi:10.1186/s12882-016-0399-z

20. Hornik B, Janusz-Jenczeń M, Włodarczyk I. Przestrzeganie zaleceń aktywności fizycznej przez chorych hemodializowanych. Dybińska E, Szpringer M, Asienkiewicz R, editors. Profilaktyka I Edukacja Zdrowotna. Lublin: Wydawnictwo Naukowe Neurocentrum. 2017. 109-122. ISBN: 978-83-61495-79-6.

21. Storer TW. Exercise Training for Individuals with Advanced Chronic Kidney Disease. In: Joel D, editor. Nutritional Management of Renal Disease. 3rd ed. Amsterdam: Academic Press; 2013:739-773.

22. Arem H, Moore SC, Patel A, et al. Leisure time physical activity and mortality: a detailed pooled analysis of the dose-response relationship. JAMA Intern Med. 2015;175(6):959-967. doi:10.1001/ jamainternmed.2015.0533

23. Nowicki M, Murlikiewicz K, Jagodzińska M. Pedometers as a means to increase spontaneous physical activity in chronic hemodialysis patients. J Nephrol. 2010;23(3):297-305.

24. Brończyk-Puzoń A, Koszowska A, Bieniek J, Podstawowe pomiary antropometryczne i pochodne wskaźniki w poradnictwie dietetycznym część pierwsza. Piel Zdr Publ. 2018;8:217-222. doi:10.17219/pzp/92366

25. Drozdowski Z. Antropometria w wychowaniu fizycznym. Wyd. 4 zm i uzup. Poznań: akademia Wychowania Fizycznego im. Eugeniusza Piaseckiego w Poznaniu. 1998. ISBN: 83-86336-51-X.

26. Heiwe S, Jacobson SH. Exercise training for adults with chronic kidney disease. Cochrane Database Syst Rev. 2011;10:CD003236. doi:10.1002/14651858.CD003236.pub2

27. Anding K, Bär T, Trojniak-Hennig J, et al. A structured exercise programme during haemodialysis for patients with chronic kidney disease: clinical benefit and long-term adherence. BMJ Open. 2015;5 (8):e008709. doi:10.1136/bmjopen-2015-008709

28. Manfredini F, Mallamaci F, and D'Arrigo G, et al. Exercise in patients on dialysis: a multicenter, randomized clinical trial. $J \mathrm{Am}$ Soc Nephrol. 2017;28(4):1259-1268. doi:10.1681/ASN.2016030378

29. Baggetta R, D'Arrigo G, Torino C, et al. Effect of a home based, low intensity, physical exercise program in older adults dialysis patients: a secondary analysis of the EXCITE trial. BMC Geriatr. 2018;18 (1):248. doi:10.1186/s12877-018-0938-5

30. Cook WL, Jassal SV. Functional dependencies among the elderly on hemodialysis. Kidney Int. 2008;73(11):1289-1295. doi:10.1038/ ki.2008.62

31. Weber-Nowakowska K, Gębska M, Myślak M, ŻyżniewskaBanaszak E, Stecko M. Rola aktywności fizycznej w leczeniu pacjentów z przewlekłą chorobą nerek. Pomeranian J Life Sci. 2017;63:27-30. doi:10.21164/pomjlifesci.247
32. Johansen KL, Chertow GM, Ng AV, et al. Physical activity levels in patients on hemodialysis and healthy sedentary controls. Kidney Int. 2000;57(6):2564-2570. doi:10.1046/j.1523-1755.2000.00116.x

33. Kutner NG, Zhang R, Huang Y, and Johansen KL. Depressed mood, usual activity level, and continued employment after starting dialysis. Clin J Am Soc Nephrol. 2010;5(11):2040-2045. doi:10.2215/CJN.03980510

34. Delgado C, Johansen KL. Barriers to exercise participation among dialysis patients. Nephrol Dial Transplant. 2012;27(3):1152-1157. doi:10.1093/ndt/gfr404

35. Wojczyk A. Problemy codziennego życia hemodializowanych pacjentów. Piel Zdr Publ. 2014;4:143-148.

36. Goodman ED, Ballou MB. Perceived barriers and motivators to exercise in hemodialysis patients. Nephrol Nurs J. 2004;31(1):23-29.

37. Jayaseelan G, Bennett PN, Bradshaw W, Wang W, and Rawson H. Exercise benefits and barriers: the perceptions of people receiving hemodialysis. Nephrol Nurs J. 2018;45(2):185-219.

38. Nowicki M, Jagodzińska M, Murlikiewicz K, Niewodniczy M. Aktywność fizyczna chorych przewlekle dializowanych porównanie skuteczności różnych metod jej zwiększania. Post Nauk Med. 2009;10:799-804.

39. Cobo G, Gallar P, Gama-Axelsson T, et al. Clinical determinants of reduced physical activity in hemodialysis and peritoneal dialysis patients. J Nephrol. 2015;28(4):503-510. doi:10.1007/s40620-0140164-y

40. Gombos GC, Bajsz V, Pék E, et al. Direct effects of physical training on markers of bone metabolism and serum sclerostin concentrations in older adults with low bone mass. BMC Musculoskelet Disord. 2016;17(1). doi:10.1186/s12891-016-1109-5

41. Janik M, Stuss M, Michalska-Kasiczak M, Jegier A, Sewerynek E. Effects of physical activity on sclerostin concentrations. Endokrynol Pol. 2018;69(2):142-149. doi:10.5603/EP.a2018.0008

42. Ardawi MSM, Al-Kadi HA, Rouzi AA, Quari MH. Determinants of serum sclerostin in healthy pre- and postmenopausal women. $J$ Bone Miner Res. 2011;26(12):2812-2822. doi:10.1002/jbmr.479

43. Frings-Meuthen P, Boehme G, Liphard A-M, Baecker N, Heer M. Rittweger J. Sclerostin and DKK1 levels during 14 and 21 days of bed rest in healthy young men. $J$ Musculoskelet Neuronal Interact. 2013;13(1):45-52.

44. Gaudio A, Pennisi P, Bratengeier C, et al. Increased sclerostin serum levels associated with bone formation and resorption markers in patients with immobilization-induced bone loss. J Clin Endocrinol Metab. 2010;95(5):2248-2253. doi:10.1210/jc.2010-0067

45. Carrero JJ, Stenvinkel P, Cuppari L, et al. Etiology of the proteinenergy wasting syndrome in chronic kidney disease: a consensus statement from the International Society of Renal Nutrition and Metabolism (ISRNM). J Ren Nutr. 2013;23(2):77-90. doi:10.1053/j. jrn.2013.01.001

46. Stenvinkel P, Ketteler M, and Johnson RJ, et al. IL-10, IL-6, and TNF-alpha: central factors in the altered cytokine network of uremia - the good, the bad, and the ugly. Kidney Int. 2005;67(4):1216-1233. doi:10.1111/j.1523-1755.2005.00200.x

47. Cheema BSB, Abas H, Smith BCF, et al. Effect of resistance training during hemodialysis on circulating cytokines: a randomized controlled trial. Eur J Appl Physiol. 2011;111(7):1437-1445. doi:10.10 07/s00421-010-1763-5

48. Daniilidis M, Kouidi E, Giagoudaki F, et al. The immune response in hemodialysis patients following physical training. Sport Sci Health. 2004;1(1):11-16. doi:10.1007/s11332-004-0003-y

49. Kasapis C, Thompson PD. The effects of physical activity on serum C-reactive protein and inflammatory markers: a systematic review. $J$ Am Coll Cardiol. 2005;45(10):1563-1569. doi:10.1016/j.jacc.2004. 12.077

50. Colbert LH, Visser M, and Simonsick EM, et al. Physical activity, exercise, and inflammatory markers in older adults: findings from the health, aging and body composition study. J Am Geriatr Soc. 2004;52 (7):1098-1104. doi:10.1111/j.1532-5415.2004.52307.x 
51. Hamer M, Sabia S, Batty GD, et al. Physical activity and inflammatory markers over 10 years follow up in men and women from the Whitehall II cohort study. Circulation. 2012;126(8):928-933. doi:10.1161/CIRCULATIONAHA.112.103879

52. Huang JH, Li RH., Huang SL, Sia HK, Hsu WT, Tang FC. HealthAssociated Nutrition and. Exercise Behaviors in Relation to Metabolic Risk Factors Stratified by Body Mass Index. Int $J$ Environ Res Public Health. 2019;16(5). doi:10.3390/ijerph1 6050869
53. Fujino $\mathrm{Y}$, Ishimura $\mathrm{E}$, Okuno $\mathrm{S}$, et al. Annual fat mass change is a significant predictor of mortality in female hemodialysis patients. Biomed Pharmacother. 2006;60(5):253-257. doi:10.1016/j.biopha.20 06.04.001

54. McPhee J, French D, Jackson D, Nazroo J, Pendleton N, Degens H. Physical activity in older age: perspectives for healthy ageing and frailty. Biogerontology. 2016;17(3):567-580. doi:10.1007/s10522016-9641-0

\section{Publish your work in this journal}

Risk Management and Healthcare Policy is an international, peerreviewed, open access journal focusing on all aspects of public health, policy, and preventative measures to promote good health and improve morbidity and mortality in the population. The journal welcomes submitted papers covering original research, basic science, clinical \& epidemiological studies, reviews and evaluations, guidelines, expert opinion and commentary, case reports and extended reports. The manuscript management system is completely online and includes a very quick and fair peer-review system, which is all easy to use. Visit http://www.dovepress.com/testimonials.php to read real quotes from published authors.

Submit your manuscript here: https://www.dovepress.com/risk-management-and-healthcare-policy-journal 